\title{
Performance and carcass traits of Moxotó growing goats supplemented on native pasture under semiarid conditions
}

\author{
Carlo Aldrovandi Torreão Marques ${ }^{1}$, Ariosvaldo Nunes de Medeiros ${ }^{2}$, Roberto Germano \\ Costa $^{3}$, Francisco Fernando Ramos de Carvalho ${ }^{4}$, Marcos Jácome de Araújo ${ }^{1}$, Jacira Neves da \\ Costa Torreão ${ }^{1}$
}

\author{
${ }^{1}$ Programa de Doutorado Integrado em Zootecnia, UFC/UFPB/UFRPE, Areia, PB, Brasil. \\ ${ }^{2}$ Departamento de Zootecnia, UFPB, Areia, PB, Brasil. \\ ${ }^{3}$ Departamento de Agropecuária, UFPB, Bananeiras, PB, Brasil. \\ ${ }^{4}$ Departamento de Zootecnia, UFRPE, Recife, PE, Brasil.
}

\begin{abstract}
The objective of the present study was to assess the growth performance and carcass traits of Moxotó goat kids fed different levels concentrate (supplement) (SL) on native pasture under semiarid conditions in Brazil. Thirty-two castrated kids ( $15.7 \pm 0.78 \mathrm{~kg}$ initial BW) were allocated randomly to one of the four SL (treatment groups: $0,5,10 \mathrm{and} 15 \mathrm{~g} / \mathrm{kg} \mathrm{BW}$ ). When the animals of treatment group $15 \mathrm{~g} / \mathrm{kg} \mathrm{BW}$ reached $25 \mathrm{~kg} \mathrm{BW}$, the animals in the other treatments groups were also slaughtered. Therefore, the animals belonging to the $0,5,10$ and $15 \mathrm{~g} / \mathrm{kg}$ of BW were finished with $18.40,21.04,22.94$ and $25.74 \mathrm{~kg}$ of BW, respectively. The concentrate supplementation positively influenced the performance and the carcass traits of animals, providing higher feed intake and thus greater weight gain. The results of cold carcass yields were 405.9, 427.0, 449.1 and $462.9 \mathrm{~g} / \mathrm{kg}$ of SBW for $0,5,10$ and $15 \mathrm{~g} / \mathrm{kg} \mathrm{BW}$, respectively. The weight of the different commercial cuts, (neck, ribs, shoulder, loin and leg) increased linearly as the SL increased; however the yields of the carcass cuts were not influenced, except for the shoulder. Overall, the distribution of non-carcass fat increased as SL increased, with the exception of mesenteric fat yield, which was not influenced. The use of concentrate supplementation to Moxotó goats under grazing conditions on native rangelands of the Brazilian semiarid improves the performance of animals and carcass yield, but does not affect the yields of commercial cuts of Moxotó growing goats.
\end{abstract}

Key Words: caatinga, fasting loss, indigenous goats, non-carcass fat, supplemental feeding

\section{Introduction}

Indigenous goats play an important role in the semiarid region of Brazil as a biological resource with great genetic variability and historical value. In addition, they are a source of animal protein of high biological value, available to people of low income. Goat breeding in the Brazilian semiarid is characterized mainly by indigenous animals raised extensively on native pastures where the nutritional needs of animals are entirely met by using natural pastures. Thus, forage represents the main and most economical source of nutrients for goats in this region, which are affected by the seasonality of forage production.

In developing countries, because of the low productivity of indigenous breeds and inadequate environmental circumstances in traditional farming systems in rural areas, solutions must be aimed at genetic improvement (genetic selection and crossbreeding), development of new feeding strategies and improvement of farming systems (Gökdal, 2013). Thus, successful livestock production requires the application of strategies that optimize the use of the environment and available nutrient sources so as to capitalize on the production potential of livestock. For the effective use of native pasture, supplementation is needed in order to meet the nutritional requirements of goats, especially for the small producer (Kanani, 2006; Silva et al., 2010).

In the Brazilian Northeast, the body weight of goats is a sales parameter. According to Mattos et al. (2006) the body weight of goats traditionally sold for slaughter varies from 25 to $30 \mathrm{~kg} \mathrm{BW}$, resulting in average carcass weights of 12 to $13 \mathrm{~kg}$, usually from animals over one year-old. Nevertheless, production and sale of kids is not well organized among the goat breeders. There is no standard method for raising and fattening kids to improve the quality and quantity of meat. The production is completely dominated by the traditional and natural conditions in this system. In addition, the lack of standards for commercial cuts constitutes one of factors that interfere with goat carcass sales.

Several studies have been conducted to characterize the growth and carcass and meat traits of goats under intensiverearing conditions. Therefore, more studies are needed to improve our knowledge of growth and carcass traits of 
indigenous goats in different conditions. The objective of the present study was to assess the performance and carcass traits of Moxotó goat kids fed different concentrate levels on native pastures in semiarid conditions in Brazil.

\section{Material and Methods}

The experiment was conducted at the Experimental Station of Universidade Federal da Paraíba - UFPB, located in the municipality of São João do Cariri (Paraiba State, Brazil), at coordinates $7^{\circ} 29^{\prime} 34^{\prime \prime S}$ and $36^{\circ} 41^{\prime} 53^{\prime \prime} \mathrm{W}$. The climate of the experimental site is a $B s h$ type (hot semiarid) according to the Köppen classification, and its vegetation is typical of the Caatinga biome. The average maximum and minimum temperatures during the experimental period (from May 2005 to March 2006) were $31.45^{\circ} \mathrm{C}$ and $20.11^{\circ} \mathrm{C}$, respectively; relative humidity was $61.2 \%$ and average precipitation was $44.26 \mathrm{~mm}$. Humane animal care and handling procedures were followed according to the animal care committee of the university.

Thirty-two Moxotó castrated kids with average initial body weight (BW) of $15.7 \pm 0.78 \mathrm{~kg}$ and approximately at about four months old were used. The kids were allocated randomly to four treatments that consisted of four concentrate supplementation levels (treatment groups: 0, 5, 10 and $15 \mathrm{~g} / \mathrm{kg} \mathrm{BW}$ ). These kids were pair-fed in eight slaughter groups. A slaughter group consisted of one kid from each treatment, and they were slaughtered when the animals from group $15 \mathrm{~g} / \mathrm{kg} \mathrm{BW}$ reached $25 \mathrm{~kg} \mathrm{BW}$.

The animals had access to native pasture from $7.00 \mathrm{~h}$ to $16.00 \mathrm{~h}$, when they were allocated to a pen equipped with individual stalls of $2.0 \times 1.0 \mathrm{~m}$, without coverage, with ground floor, to receive the supplementation. The animals had free access to drinking water, and the collective fountains were located at the management center and the experimental concentrate was the same for all treatments, only varying the amount offered to the animals once a day $(16.00 \mathrm{~h})$. The refused feed was weighed, recorded and sampled in the morning of the next day. The amounts of ingredients and nutrients of the experimental concentrate (Table 1) were calculated according to the NRC (1981) so as to provide a growth rate of $150 \mathrm{~g} /$ day for the animals with $15 \mathrm{~g} / \mathrm{kg}$ BW supplementation level. To control the growth and adjust the concentrate supply, the animals were weighed weekly, before feeding, with a scale with precision of $0.1 \mathrm{~kg}$.

The experimental area was composed of two paddocks of approximately 8 ha each. The occurrence percentage and the availability of botanical components analyzed in the experimental area during the trial were estimated
Table 1 - Ingredient and chemical composition of the experimental concentrate (g/kg DM)

\begin{tabular}{lc}
\hline Item & $\mathrm{g} / \mathrm{kg} \mathrm{DM}$ \\
\hline Ingredient & \\
Corn meal $^{1}$ & 580 \\
Soybean meal & 270 \\
Wheat meal & 50 \\
Cottonseed meal & 50 \\
Limestone & 10 \\
Mineral supplement & 40 \\
Composition & $\mathrm{g} / \mathrm{kg} \mathrm{DM}$ \\
Dry matter & 875.85 \\
Crude protein & 202.55 \\
Gross energy (Mcal/kg DM) & 4.30 \\
Digestible energy (Mcal/kg DM) & 2.83 \\
Metabolizable energy (Mcal $/ \mathrm{kg} \mathrm{DM})^{3}$ & 3.14 \\
Neutral detergent fiber & 167.20 \\
Acid detergent fiber & 60.0 \\
Calcium & 8.14 \\
Phosphorus & 8.50 \\
\hline
\end{tabular}

${ }^{1}$ By-product from the manufacture of corn flakes.

${ }^{2}$ Calculated from the gross-energy digestibility coefficient.

${ }^{3}$ Estimated considering $82 \%$ of digestible energy (NRC, 1989).

by Gonzaga (2007), demonstrating the predominance of Panasco grass (Aristida setifolia. H.B.K.) with $450.04 \mathrm{~g} / \mathrm{kg}$, followed by Marmeleiro (Croton sonderianus Muell.Arg.), with $120.79 \mathrm{~g} / \mathrm{kg}$, and other grasses with $86.8 \mathrm{~g} / \mathrm{kg}$. The percentages shown for the other components were $45.9 \mathrm{~g} / \mathrm{kg}$ Pinhão roxo (Jatropha gossypiifolia $\mathrm{L}$.), $61.9 \mathrm{~g} / \mathrm{kg}$ Malva branca(Sida cordifolia L.), $51.6 \mathrm{~g} / \mathrm{kg}$ Catingueira(Caesalpinia pyramidalis Tull.), $68.8 \mathrm{~g} / \mathrm{kg}$ Pereiro (Aspidosperma pyrifolium Mart), $58.3 \mathrm{~g} / \mathrm{kg}$ Cacti, $14.6 \mathrm{~g} / \mathrm{kg}$ other shrubs and $33.9 \mathrm{~g} / \mathrm{kg}$ other herbs. The average availability was estimated at $1.350 \mathrm{~kg}$ of natural mass $/ \mathrm{ha}$.

The concentrate was fed at approximately $16.00 \mathrm{~h}$ aiming to condition the animals to gather in a specific area for assessment purposes. Concentrate was normally rapidly consumed; in case it rained, concentrate remainders were collected and offered the next day before releasing the animals for grazing. Animals were individually tagged by numbered rings. During the pre-experimental period (15 days) the animals were given worm medication which was repeated every 90 days during the seven months of the experiment.

In addition to the performance and carcass assessment, a trial to estimate the dry matter intake (DMI), chemical composition and in vitro digestibility of diet of the animals on pasture was conducted. Eight animals canulated in the esophagus with an average weight of $25.83 \pm 4.48 \mathrm{~kg}$ BW were used in a double Latin square design $(4 \times 4)$. The trial comprised four periods: each period had 28 days of adaptation to the diet and eight days for data collection. The canulated animals received the same 
feeding supplementation levels as the other animals in the experiment. The statistical model used in the DMI-estimate trial was the following:

$$
Y_{i j k l}=\mu+Q_{l}+T_{i}+P_{k}+A_{(j) l}+Q T_{l i}+\xi_{i j k},
$$

in which $Y_{i j k l}=$ observation of goat $j$ in period $k$, subjected to treatment $i$, with $i, j$, and $k=1,2,3,4 ; \mu=$ overall effect of the mean; $Q_{l}=$ effect of the Latin square, with $Q_{l}=1,2$; $T_{i}=$ effect of treatment $i ; P_{k}=$ effect of period $k ; A_{(j) l}=$ effect of goat $j$ in square $l ; Q T_{l i}=$ interaction of the effect of Latin square $l$ with treatment $i$; and $\xi_{i j k}=$ random error associated with each observation $Y_{i j k l}$.

The extrusa collection was held for eight consecutive days, in alternating shifts, forming four full collection days for each animal (4 mornings and 4 afternoons). During the morning collection, the fistulated animals (held in sheds) were subjected to a previous feed deprivation period of approximately 12 hours before sampling with salt-mineral water ad libitum. In the morning, the cannulas were removed and coupled to the extrusa collecting bags, which were made of synthetic leather with a nylon mesh bottom to reduce excess saliva. The grazing period was approximately 40 minutes. After sampling, the animals were driven back to the management center for the removal of bags and placement of cannulas, and then they were released in their paddocks. For the afternoon collection, the animals were removed from the pasture 4 hours before sampling to avoid regurgitation and contamination of the experimental samples; then, the same procedures as those of the morning collection were performed.

The extrusa samples were made taking into account the experimental period and the animal. The chemical composition of the extrusa was $231.1 \mathrm{~g} / \mathrm{kg}$ of dry matter (DM), $460 \mathrm{~g} / \mathrm{kg}$ of in vitro digestibility of DM, $113.0 \mathrm{~g} / \mathrm{kg}$ of mineral matter (MM), $123.4 \mathrm{~g} / \mathrm{kg}$ of crude protein $(\mathrm{CP})$, 36.1 Mcal of gross energy (GE) $/ \mathrm{kg} \mathrm{DM}, 538.5 \mathrm{~g} / \mathrm{kg}$ of neutral detergent fiber (NDF), $451.2 \mathrm{~g} / \mathrm{kg}$ of acid detergent fiber (ADF) and $176.5 \mathrm{~g} / \mathrm{kg}$ of lignin.

The pasture DMI was estimated through the total feces excretion and DM digestibility of diet, as follows:

$$
\begin{gathered}
\mathrm{DMI}=[(100 \times \text { Fecal excretion, } \mathrm{kg} \mathrm{DM} / \text { day }) /(100-\mathrm{DM} \\
\text { digestibility of extrusa })]
\end{gathered}
$$

The total feces collection was performed using collecting bags attached to animals, collected in the early morning $(7.00 \mathrm{~h})$ and late afternoon $(17.00 \mathrm{~h})$. After the material from each bag was homogenized, aliquots of $200 \mathrm{~g} / \mathrm{kg}$ of total excreted for 24 hours were removed to form samples per animal and period, which were wrapped in properly identified plastic bags and frozen.

After the experimental period, samples were thawed, weighed and dried in a forced-ventilation oven at $55{ }^{\circ} \mathrm{C}$ for
72 hours, and ground through a 1-mm screen Wiley mill (Arthur H. Thomas Co., Philadelphia, PA). The in vitro DM digestibility was determined on an artificial rumen (DAYSE II; ANKON Technology Coorp., Fairport, NY) based on methodology adapted from Tilley and Terry et al. (1963).

The DMI values of the fistulated animals $\left(\mathrm{kg}^{0.75}\right.$ of BW) were regressed against the supplementation levels $(\mathrm{SL}=0$, 5, 10 and $15 \mathrm{~g} / \mathrm{kg} \mathrm{BW})$, generating the equation:

$$
\mathrm{DMI}=0.0677+0.0086 \times \mathrm{SL}-0.0141 \times \mathrm{SL}^{2}
$$

After applying the level of supplementation in the equation we obtained $0.068,0.068,0.062$ and $0.049 \mathrm{~kg}$ of $\mathrm{DM} / \mathrm{kg}^{0.75}$ of BW per day for $0,5,10$ and $15 \mathrm{~g} / \mathrm{kg} \mathrm{BW}$, respectively. These values were then used to estimate the DMI of all animals in the experiment according to the equation below:

DMI $($ from pasture $)=\mathrm{kg}^{0.75}$ of BW (all animals $) \times$ DMI

( $\mathrm{kg}$ of DM/ $\mathrm{kg}^{0.75}$ of BW from fistulated animals).

The total DMI was equal to the sum of pasture intake plus the concentrate intake. The ingredients and extrusa were analyzed for DM (AOAC, 1990; method number 930.15), mineral matter (AOAC, 1990; method number 924.05) and crude protein (AOAC, 1990; method number 984.13). The gross energy (GE) was determined using a Parr bomb calorimeter (Parr Instrument Co., Moline, IL) and the digestible energy (DE) was determined from the GE of the feed consumed (extrusa and concentrate) and feces. The metabolizable energy was estimated as $82 \%$, considering the DE (NRC, 1989). Neutral detergent fiber (NDF), acid detergent fiber (ADF) and lignin (sequential procedure described by Van Soest et al., 1991) without sodium sulfite or amylase, except in the corn grain, were obtained using the fiber analyzer of Ankom Technology Corporation (Macedon, NY, USA), without correction for residual ash.

The goats were weighed pre-fasting and after having fasted for 16 hours, but with access to water. Shrunk BW (SBW) was measured immediately before slaughter. The goats were slaughtered and dressed down using standard commercial techniques. At slaughter, the kids were stunned through brain concussion, and killed by exsanguination using conventional humane procedures. Following skinning and evisceration, the digestive tract was emptied and weighed to obtain empty body weight (EBW) and the real or biologic yield (BY) of the carcass according to the methodology described by Silva Sobrinho (2001):

$$
\mathrm{BY}(\mathrm{g} / \mathrm{kg} \mathrm{EBW})=[(\mathrm{HCW}, \mathrm{kg} / \mathrm{EBW}, \mathrm{kg}) \times 100] .
$$

The hot carcass comprised the body after removing the skin, head, fore feet (at the carpal-metacarpal joint), hind feet (at the tarsal-metatarsal joint), viscera and fat depots. Internal organs (kidneys, liver, heart, lungs, spleen and 
pancreas) and fat depots such as scrotal fat, pelvic, kidney and gut fats (omental + mesenterict) were also removed. The hot carcass yield (HCY) was defined as the HCW expressed as a percentage of SBW, as follows:

$$
\mathrm{HCY}(\mathrm{g} / \mathrm{kg} \mathrm{SBW})=[(\mathrm{HCW}, \mathrm{kg} / \mathrm{SBW}, \mathrm{kg}) \times 100] .
$$

The total edible proportion (TEP) was the SBW minus the contents of gastro-intestinal tract, skin, head, feet and lungs and trachea.

Cold carcass weight (CCW) was measured after 24 hours of chilling at $4{ }^{\circ} \mathrm{C}$. At the end of this period, the cold carcass yield (CCY) was defined as the CCW expressed as a percentage of SBW, calculated as follows:

$\mathrm{CCY}(\mathrm{g} / \mathrm{kg} \mathrm{SBW})=[(\mathrm{CCW}, \mathrm{kg} / \mathrm{SBW}, \mathrm{kg}) \times 100]$.

Chilling and fasting losses were calculated as follows:

$$
\begin{gathered}
\mathrm{CHL}(\mathrm{g} / \mathrm{kg} \mathrm{HCW})=\{[(\mathrm{HCW}, \mathrm{kg}-\mathrm{CCW}, \mathrm{kg}) / \mathrm{HCW}, \mathrm{kg}] \times \\
100\} ; \text { and } \\
\mathrm{FL}(\mathrm{g} / \mathrm{kg} \mathrm{SBW})=\{[(\mathrm{BW}, \mathrm{kg}-\mathrm{SBW}, \mathrm{kg}) / \mathrm{SBW}, \mathrm{kg}] \times \\
100\}, \text { respectively. }
\end{gathered}
$$

The carcass length (caudal edge of the last sacral vertebra to the dorso-cranial edge of the atlas) was measured $(\mathrm{CL}, \mathrm{cm})$. Carcass compactness was defined as the ratio of cold carcass weight to carcass length $(\mathrm{CC}, \mathrm{kg} / \mathrm{cm}=\mathrm{CCW}$, $\mathrm{kg} / \mathrm{CL}, \mathrm{cm})$.

After removing the tail at the last sacral/first coccygeal vertebrae articulation, the cold carcass was split along the dorsal mid-line with a band saw. The left half of the carcass was partitioned into leg, loin, ribs, shoulder and neck according to the procedure of Colomer-Rocher et al. (1988). The leg from the right half of each carcass was dissected and the tissues were separated to estimate the total carcass composition in terms of lean (muscle), bone and fat.

The experimental design was completely randomized, with four treatments, according to the statistical model:

$$
\mathrm{Y}_{i j}=\mu+\mathrm{t}_{i}+\mathrm{e}_{i j} \text {, }
$$

in which $\mathrm{Y}_{i j}=$ value observed in the plot that received the treatment $i$ in the repetition $j ; \mu=$ overall mean of the population; $\mathrm{t}_{i}=$ effect of treatment $i$; and $\mathrm{e}_{i j}=$ random error.

The statistical analyses were performed using the SAS (Statistical Analysis System, version 9.0). The data were tested for homogeneity of variances through Bartlett's test (PROC GLM) and normality of errors through the Shapiro-Wilk test (PROC UNIVARIATE), prerequisites for the analysis of variance. Procedure PROC MEANS was used to obtain the means and standard error. For the linear regression analyses we used the model $y=a+b x$, which shows the behavior of the dependent variable $y$ as a function of the independent variable $\mathrm{x}$, using procedure PROC REG, and significance was declared if $\mathrm{P}<0.05$.

\section{Results}

Supplementation positively influenced the performance of animals, providing higher feed intake and therefore greater weight gain (Table 2). Although one of the animals that received no supplementation died during the experiment, all unsupplemented kids showed an increase of $143 \mathrm{~g} / \mathrm{kg}$ in the final BW, whereas the kids receiving the highest level of supplementation gained about $390 \mathrm{~g} / \mathrm{kg}$ BW (Table 2).

The DMI values obtained in the present study varied from 569.67 to $789.80 \mathrm{~g} / \mathrm{day}$, from 33.3 to $37.9 \mathrm{~g} / \mathrm{kg}$ of BW and from 67.91 to $81.80 \mathrm{~g} / \mathrm{kg}^{0.75} /$ day. Final weight, ADG and feed efficiency were positively and linearly influenced $(\mathrm{P}<0.001)$ by the supplementation levels (Table 2$)$.

Carcass traits increased linearly as the supplementation level increased, except for chilling and fasting losses (Table 3). In the present study, cold carcass yield varied from 405.9 to $462.9 \mathrm{~g} / \mathrm{kg} \mathrm{SBW}$ for 0 and $15 \mathrm{~g} / \mathrm{kg} \mathrm{BW}$ of

\begin{tabular}{|c|c|c|c|c|c|c|c|}
\hline \multirow{2}{*}{ Item } & \multicolumn{4}{|c|}{ Supplementation level (g/kg BW) } & \multirow{2}{*}{ SEM } & \multicolumn{2}{|c|}{ P-value } \\
\hline & 0 & 5 & 10 & 15 & & $\mathrm{~L}$ & Q \\
\hline $\mathrm{n}$ & 7 & 8 & 8 & 8 & - & - & - \\
\hline Days on feed & 156 & 156 & 156 & 156 & - & - & - \\
\hline Initial body weight (kg) & 15.77 & 15.72 & 15.71 & 15.72 & - & - & - \\
\hline Final body weight (kg) & 18.40 & 21.04 & 22.94 & 25.74 & 0.66 & 0.0001 & 0.9317 \\
\hline Total weight gain $(\mathrm{kg})$ & 3.08 & 6.08 & 7.22 & 10.02 & 0.66 & 0.0003 & 0.8511 \\
\hline Average daily gain (g/day) & 18.53 & 38.55 & 46.66 & 65.81 & 4.01 & $<0.0001$ & 0.8046 \\
\hline Dry matter intake (g/day) & 569.67 & 703.73 & 772.34 & 789.80 & 16.83 & $<0.0001$ & 0.0004 \\
\hline Dry matter intake (g/kg BW) & 33.30 & 37.39 & 39.70 & 37.94 & 0.44 & $<0.0001$ & $<0.0001$ \\
\hline Dry matter intake $\left(\mathrm{g} / \mathrm{kg}^{0.75} /\right.$ day $)$ & 67.91 & 79.53 & 84.13 & 81.80 & 1.11 & $<0.0001$ & $<0.0001$ \\
\hline Feed efficiency (g/kg DM) & 37.91 & 53.11 & 59.71 & 83.03 & 4.33 & $<0.0001$ & 0.7832 \\
\hline
\end{tabular}
supplementation, respectively.

In this study, the total edible proportion ranged from 616.5 to $682.7 \mathrm{~g} / \mathrm{kg}$ of SBW. Chilling and fasting losses were not affected by supplementation levels, averaging

Table 2 - Growth performance of Moxotó goats grazing in the semiarid region of Brazil subjected to supplementation levels

SEM - standard error of the mean; L - linear effect; Q - quadratic effect. 
$46.77 \mathrm{~g} / \mathrm{kg}$ of $\mathrm{HCW}$ and $79.81 \mathrm{~g} / \mathrm{kg}$ of SBW, respectively. Carcass length and carcass compactness index increased $(\mathrm{P}<0.05)$ as the supplementation level increased (Table 3), varying from 53.29 to $67.75 \mathrm{~cm}$ and from 0.130 to $0.162 \mathrm{~kg} / \mathrm{cm}$, respectively.

The increase in carcass weight as supplementation levels increased reflected in increase in the weight of commercials cuts (neck, ribs, shoulder, loin and leg). However, the proportions of the primal cuts were similar, except for the shoulder, which deceased as supplementation increased $(\mathrm{P}<0.003$; Table 4$)$. The data on weights of wholesale cuts of the left half-carcass indicated that as supplementation increased, the goats yielded better carcasses with more developed leg, neck, ribs, loin and shoulder.

The proportions of muscle showed a quadratic effect, fat increased linearly, and bone decreased linearly as the kids increased the weight of their leg in response to the elevated supplementation level (Table 5). The results show a linear increase in the muscle mass in relation to bone tissue as the weight of the leg increased; muscle: fat and bone:fat ratios decreased linearly. During the leg dissection, the tissues not identified as muscle, bone or fat were classified as other tissues and included in the leg weight recomposition; however, they were not assessed, which is why the total percentage of muscle, bone and fat did not reach $100 \%$.

The non-carcass fat contents of Moxotó goats increased as the supplementation level increased, with the exception of mesenteric fat yield, which was not affected (Table 6). Regarding the total non-carcass fat, mesenteric fat showed a greater proportion in the animals fed 0,10 and $15 \mathrm{~g} / \mathrm{kg}$ of BW concentrate. On the other hand, in the animals that received the highest level of supplementation, omental fat was the main deposit represented in total noncarcass fat.

Table 3 - Slaughter and carcass characteristics of Moxotó goats grazing in the semiarid region of Brazil subjected to supplementation levels

\begin{tabular}{|c|c|c|c|c|c|c|c|}
\hline \multirow{2}{*}{ Item } & \multicolumn{4}{|c|}{ Supplementation level (g/kg BW) } & \multirow{2}{*}{ SEM } & \multicolumn{2}{|c|}{ P-value } \\
\hline & 0 & 5 & 10 & 15 & & $\mathrm{~L}$ & Q \\
\hline Pre-slaughter BW (kg) & 18.40 & 21.04 & 22.94 & 25.74 & 0.66 & 0.0001 & 0.9317 \\
\hline Shrunk BW (kg) & 16.82 & 19.44 & 21.25 & 23.43 & 0.58 & $<0.0001$ & 0.7909 \\
\hline Fasting loss (g/kg SBW) & 82.96 & 75.31 & 71.74 & 89.63 & 5.29 & 0.7409 & 0.2499 \\
\hline Empty BW (kg) & 13.09 & 15.58 & 17.69 & 19.72 & 0.56 & $<0.0001$ & 0.7564 \\
\hline Hot carcass weight (kg) & 7.11 & 8.76 & 10.07 & 11.45 & 0.37 & $<0.0001$ & 0.7937 \\
\hline Cold carcass weight $(\mathrm{kg})$ & 6.84 & 8.34 & 9.57 & 10.83 & 0.35 & $<0.0001$ & 0.7993 \\
\hline Hot carcass yield (g/kg SBW) & 421.86 & 448.00 & 471.81 & 489.39 & 6.95 & 0.0001 & 0.7025 \\
\hline Cold carcass yield (g/kg SBW) & 405.90 & 427.00 & 449.06 & 462.88 & 6.21 & 0.0003 & 0.7245 \\
\hline Biological yield (g/kg EBW) & 541.90 & 560.19 & 566.98 & 581.19 & 5.16 & 0.0074 & 0.8318 \\
\hline Chilling loss (g/kg HCW) & 37.41 & 46.86 & 47.60 & 54.07 & 3.36 & 0.1099 & 0.8260 \\
\hline Total edible proportion ( $\mathrm{g} / \mathrm{kg}$ SBW) & 616.49 & 634.98 & 667.47 & 682.68 & 5.90 & $<0.0001$ & 0.8298 \\
\hline Carcass length $(\mathrm{cm})$ & 53.29 & 57.87 & 64.94 & 67.75 & 1.47 & $<0.0001$ & 0.6915 \\
\hline Compactness index $(\mathrm{kg} / \mathrm{cm})$ & 0.130 & 0.145 & 0.149 & 0.162 & 0.005 & 0.0489 & 0.9597 \\
\hline
\end{tabular}

SEM - standard error of the mean; L - linear effect; Q - quadratic effect.

BW - body weight; SBW - body weight at slaughter; EBW - empty body weight; HCW - hot carcass weight.

Table 4 - Weight and proportional yields of the carcass cuts of Moxotó goats grazing in the semiarid region of Brazil subjected to supplementation levels

\begin{tabular}{|c|c|c|c|c|c|c|c|}
\hline \multirow{2}{*}{ Item } & \multicolumn{4}{|c|}{ Supplementation level (g/kg BW) } & \multirow{2}{*}{ SEM } & \multicolumn{2}{|c|}{$\mathrm{P}$-value } \\
\hline & 0 & 5 & 10 & 15 & & $\mathrm{~L}$ & Q \\
\hline \multicolumn{8}{|c|}{ Wholesale cuts of left half of the carcass $(\mathrm{kg})$} \\
\hline Neck & 0.66 & 0.78 & 0.90 & 1.01 & 0.03 & $<0.0001$ & 0.9723 \\
\hline Shoulder & 1.48 & 1.77 & 2.00 & 2.22 & 0.07 & $<0.0001$ & 0.7451 \\
\hline Ribs & 1.80 & 2.17 & 2.55 & 2.94 & 0.10 & $<0.0001$ & 0.9610 \\
\hline Loin & 0.69 & 0.90 & 1.11 & 1.17 & 0.04 & $<0.0001$ & 0.2108 \\
\hline Leg & 2.18 & 2.71 & 3.00 & 3.49 & 0.11 & $<0.0001$ & 0.9024 \\
\hline \multicolumn{8}{|c|}{ Proportional yields $(\mathrm{g} / \mathrm{kg})$ relative to empty body weight } \\
\hline Neck & 98.05 & 94.17 & 93.51 & 93.50 & 1.08 & 0.1597 & 0.3800 \\
\hline Shoulder & 216.82 & 212.79 & 208.88 & 205.59 & 1.43 & 0.0034 & 0.8850 \\
\hline Ribs & 261.82 & 260.45 & 265.79 & 271.71 & 1.96 & 0.0524 & 0.3462 \\
\hline Loin & 99.47 & 107.74 & 111.66 & 107.86 & 1.77 & 0.0661 & 0.0826 \\
\hline Leg & 319.57 & 323.92 & 314.54 & 322.01 & 1.89 & 0.9023 & 0.6794 \\
\hline
\end{tabular}

SEM - standard error of the mean; L - linear effect; Q - quadratic effect.

BW - body weight. 
Table 5 - Physical composition and relationships of tissues from leg of Moxotó goats grazing in the semiarid region of Brazil subjected to supplementation levels

\begin{tabular}{|c|c|c|c|c|c|c|c|}
\hline \multirow{2}{*}{ Item } & \multicolumn{4}{|c|}{ Supplementation level (g/kg BW) } & \multirow{2}{*}{ SEM } & \multicolumn{2}{|c|}{ P-value } \\
\hline & 0 & 5 & 10 & 15 & & $\mathrm{~L}$ & Q \\
\hline EBW (kg) & 13.09 & 15.58 & 17.69 & 19.72 & 0.56 & $<0.0001$ & 0.7564 \\
\hline Leg weight $(g)^{1}$ & 1004 & 1300 & 1394 & 1645 & 57.36 & $<0.0001$ & 0.7865 \\
\hline Bone $(\mathrm{g} / 100 \mathrm{~g})$ & 23.40 & 21.57 & 19.59 & 18.70 & 0.54 & 0.0005 & 0.6105 \\
\hline Fat $(\mathrm{g} / 100 \mathrm{~g})$ & 3.84 & 4.25 & 6.35 & 8.15 & 0.52 & 0.0006 & 0.4269 \\
\hline \multicolumn{8}{|l|}{ Ratios (g/g) } \\
\hline Bone:fat & 5.48 & 7.02 & 3.31 & 2.56 & 0.60 & 0.0184 & 0.2917 \\
\hline
\end{tabular}

${ }^{1}$ Obtained by replenishment of dissected tissues.

SEM - standard error of the mean; L - linear effect; Q - quadratic effect.

BW - body weight; EBW - empty BW.

Table 6 - Distribution of non-carcass fat of Moxotó goats grazing in the semiarid region of Brazil subjected to supplementation levels

\begin{tabular}{|c|c|c|c|c|c|c|c|}
\hline \multirow{2}{*}{ Item } & \multicolumn{4}{|c|}{ Supplementation level (g/kg BW) } & \multirow{2}{*}{ SEM } & \multicolumn{2}{|c|}{ P-value } \\
\hline & 0 & 5 & 10 & 15 & & $\mathrm{~L}$ & Q \\
\hline \multicolumn{8}{|l|}{ Weight (g) } \\
\hline Kidney-pelvic fat & 58.57 & 91.25 & 132.85 & 251.25 & 17.34 & $<0.0001$ & 0.0606 \\
\hline Mesenteric fat & 157.14 & 235.00 & 286.25 & 336.12 & 24.15 & 0.007 & 0.7553 \\
\hline Omental fat & 84.28 & 175.00 & 265.00 & 406.25 & 28.73 & $<0.0001$ & 0.5357 \\
\hline Total non-carcass fat & 300.00 & 501.25 & 715.00 & 993.62 & 65.42 & $<0.0001$ & 0.6939 \\
\hline \multicolumn{8}{|c|}{ Proportional yields $(\mathrm{g} / \mathrm{kg}$ ) relative to cold carcass weight } \\
\hline Kidney-pelvic fat & 4.44 & 5.48 & 8.87 & 12.79 & 0.87 & $<0.0001$ & 0.3123 \\
\hline Mesenteric fat & 11.5 .7 & 14.30 & 15.77 & 16.90 & 1.10 & 0.0918 & 0.7171 \\
\hline Omental fat & 6.31 & 10.35 & 14.37 & 20.61 & 1.33 & $<0.0001$ & 0.5870 \\
\hline Total non-carcass fat & 22.32 & 30.14 & 39.02 & 50.31 & 2.91 & 0.0002 & 0.7142 \\
\hline
\end{tabular}

SEM - standard error of the mean; L - linear effect; Q - quadratic effect.

\section{Discussion}

In this study, supplementation improved the performance of goats, and this response contemplates in part the objective of providing supplementation at pasture, which should facilitate the synchronization of nitrogen and carbohydrate degradability in the rumen and increase the supply of nutrients for absorption in the small intestine (Yue-ming et al., 2005), which in turn may result in better animal performance. However, the type and quantity of supplement offered may affect forage DM intake. Therefore, the need for supplementation in forage-based systems is a direct response of the insufficient amount of nutrients in the forage.

The results found for weight gain are similar to that found by Carvalho Júnior et al. (2011), who assessed the effect of supplementation on the performance of F1 (Boer $\times$ females of no defined breed) goats finished on native pasture using the same supplementation levels and range of BW used in this research. In their evaluation, Carvalho Júnior et al. (2011) observed DMI varying from 539.43 to $953.36 \mathrm{~g} /$ day, from 25.1 to $34.5 \mathrm{~g} / \mathrm{kg}$ of BW and from 50.43 to $79.66 \mathrm{~g} / \mathrm{kg}^{0.75} /$ day.
The average daily gain (ADG) obtained in this experiment can be considered similar to the weight gain of goats reared in the desert as in the findings of Ahmed et al. (2001), who studied 4-month-old kids of Black breed goats in the Sinai region located in Northern Egypt. In this case, the extensive system was applied, which resulted in a weight gain of $67 \mathrm{~g} /$ day.

The low weight gain in this study can be explained by pasture quality and that is confirmed by the extrusa composition and demonstrated by diets with low apparent digestibility coefficients of gross energy and crude protein, resulting in low intake of nutrients. In addition, the low ADG obtained in this study must be related to pasture quality and to the stocking rate of 4 goats per ha. The stocking rate used may be considered high, since the recommended values are 1 to 2 animals per ha (Araújo Filho, 2006), resulting in lower feed availability and also low forage quality (DM digestibility $=460 \mathrm{~g} / \mathrm{kg}$ ) obtained from the extrusa. In this case, factors impacting carcass quality were intrinsic. Feeding regimen is a determining factor in various carcass aspects and performance, especially when assessed for certain breeds (Boggs et al., 1998; Daskiran et al., 2010). 
Another factor that can account for low ADG, in addition to the utilized production system is the fact that the Moxoto breed used in this study did not possess the genetic potential for weight gain, that is, was not selected for meat production as are some goat breeds considered cosmopolitan for their intense selection in the obtainment of precocious animals. In the case of animals selected and raised in feedlot, weight gain result may improve and that has been demonstrated by Sheridan et al. (2000), who worked with Boer goats in a feedlot system in South Africa with ADG of $162 \mathrm{~g}$.

Usually the concentrate feed is not given to animals during the growth period. According to the results of the present study, additional feeding to grazing could be useful to provide better growth rate and final weight to goat kids. Intensive fattening of kids is not a widespread practice in the Brazilian semiarid region, except in scientific experiments. However, according to the present results, concentrate feed given to animals at least in addition to grazing can increase the growth rate of kids.

The values found for cold carcass yield are in agreement with the values reported for various goat breeds worldwide. In previous studies (Kadim et al., 2003; Daskıran et al., 2006a,b; Yañez et al., 2006; Y1lmaz et al., 2009; Y1lmaz et al., 2010; Gökdal, 2013), the dressing percentage (CCY) of kids had been reported to be around $371-492 \mathrm{~g} / \mathrm{kg}$ in different goat breeds. In the present study dressing percentage of the Moxoto kids was similar to the previous reports obtained for the same genotype under intensive fattening (Mattos et al., 2006).

As suggested by Gökdal (2013), different goat carcass dressing percentages may be attributed to differences of age and rearing conditions. In addition, the dressing percentage may vary depending on head weight (presence of horns) skin weight (presence and weight of hair), and other variables (slaughter method and practice, relative to hot carcass weight, cold carcass weight, full body weight, empty body weight or slaughter weight) taken into account in the calculations of researchers. Besides heavier carcasses and increased carcass fat, a higher plane of nutrition also typically results in a higher dressing percentage.

Total edible proportion could be a more useful criterion for comparing yields by breed and production practices. Sebsibe et al. (2007) reported comparable yields of total usable products ranging from 609 to $638 \mathrm{~g} / \mathrm{kg}$ of SBW for Ethiopian goat breeds. Chilling and fasting losses values are similar to those found by Mattos et al. (2006) for Moxotó and Canindé goats at similar BW. Chilling losses ranging from 23 to $87 \mathrm{~g} / \mathrm{kg}$ of $\mathrm{HCW}$ have been reported for different goat genotypes and weights (El Khidir et al.,
1998). Attah et al. (2004) reported that decrease in exposed surface area as carcass weight increased and more efficient insulation due to increased fatness may be responsible for the protection against dehydration. This fact was not observed in this study.

The influence of carcass weight on linear measurements and compactness indices, conformation, and subcutaneous fat has been widely reported and explained by the differential growth rates of bone, muscle and fat (Álvarez et al., 2013). Mourad et al. (2001) reported a higher compactness index $(0.19 \mathrm{~kg} / \mathrm{cm})$ than the present finding, which was mainly due to the shorter carcass length of West African Dwarf goats.

The increase in carcass weight as supplementation levels increase reflected in increased weight of commercials cuts (neck, ribs, shoulder, loin and leg). However, the proportions of primal cuts were similar, except for shoulder. This similar behavior was reported by Mattos et al. (2006) and Grande et al. (2011). These findings reinforce the law of anatomical harmony (Boccard and Dumont, 1960 cited by Siqueira et al., 2001), which states that in carcasses with similar weights and amounts of fat almost all body regions are in similar proportions regardless of the considered conformation of genotypes.

The proportion of the shoulder decreased with increasing carcass weight. Colomer-Rocher et al. (1992) found similar results, while Pereira Filho (2008) found that proportion of shoulder and neck linearly decreased as the cold carcass weight increased, obtained by rearrangement of the weights of commercial cuts. This could be explained because the Moxotó breed has a variation in breed standards. That is, in herds with high genotype and phenotype variations there is no oriented selection for meat production, therefore longlegged animals or shorter animals as well as smaller or elongated animals can be found.

The data related to physical composition and muscle: bone, muscle:fat and bone:fat ratios agree with those found in the literature, which has documented that the percentage of bone decreased significantly with age and weight while the percentage of fat increased. Overall, Moxotó kids had lower proportion of muscle in the leg, greater proportion of bone, similar proportions of fat and lower muscle:bone ratio, as compared with Boer crossbred (Boer $\times$ Saanen) kids studied by Pereira Filho et al. (2008), considering similar leg weights between genotypes.

The fat distribution in the goat carcass is quite different from other ruminant species such as sheep, because most of it is extracted in the evisceration process. In goats, about $450 \mathrm{~g} / \mathrm{kg}$ of body fat is stored in the viscera, while bovine and sheep store only $250 \mathrm{~g} / \mathrm{kg}$ (Potchoiba et al., 1990). In addition, according to Mendizabal et al. (2007), goats have higher 
fat deposition ability as well as visceral fat mobilization, and subcutaneous, intermuscular and intramuscular fat deposition in lower proportion, and that reflects the lower carcass yield in goats when compared with lambs.

The internal fat is highly variable and can be influenced by genotype (Rodrigues et al., 2013), nutrition (Bezerra et al., 2010), age, slaughter weight (Al-Owaimer et al., 2013), physiological condition, and physical activities (Solaiman et al., 2011). Higher visceral fat deposition can be explained by its more intense vascularization. Kozloski et al. (2001) reported that goats in warm climates have their visceral areas more irrigated, facilitating fat deposition and utilization, especially in cases of insufficient energy, diet limitation and intake reduction, functioning as a thermoregulatory mechanism. The purpose of these physiological changes results in glycogen synthesis, in which glucose molecules are added to chains of glycogen for storage (Voet and Voet, 2006). In this study, deposition of total non-carcass fat practically doubles its impact when compared with carcasses resulting from the lack of use of concentrate at a higher supplementation level, demonstrating that concentrate intake tends to increase non-carcass fat especially in indigenous animals.

Fat is the non-carcass component that most changes according to the feeding type. The larger amount of mesenteric fat is considered by Monte et al. (2007) a positive aspect, since it is an energy reserve that can be used by the animal during the dry period, which reduces the degradation of muscle protein during this time of year.

Supplementation with concentrate may be an alternative for increasing the growth rate of the animals and improving the stocking rate in the same area, due to the replacement of part of forage intake by supplement intake. This will allow for an improvement in production per unit area. Another aspect to be noted is that the supply of supplement can provide reduction in slaughter age and length of stay of animals on the property, which will allow for an increase in the speed of capital turnover. The findings suggest that supplemental feeding should be made in order for goat kids to achieve a good growth rate and produce good-quality carcass in rural conditions.

\section{Conclusions}

The use of concentrate supplementation for Moxotó goat kids grazing on native rangelands of the Braziliansemiarid Caatinga results in better growth rate and final weight as well as improved carcass yields; yet, it does not affect the yields of commercial cuts. In addition, lower nutritional intake also provides Moxotó goats with desirable carcasses.

\section{Acknowledgments}

The authors would like to thank Conselho Nacional de Desenvolvimento Científico e Tecnológico (CNPq) and Banco do Nordeste do Brasil for the financial support and all who contributed to the achievement of this research.

\section{References}

Ahmed, A. M.; Kandil, M. H.; El-Shaer, H. M. and Metawi, H. R. 2001. Performance of desert black goat under extensive production system in North Sinai in Egypt. p.213-217. In: Production systems and product quality in sheep and goats. Rubino, R. and Morand Fehr, P., eds. Zaragoza, Spain.

Al-Owaimer, A.; Suliman, G.; El-Waziry, A.; Metwally, H. and Abouheif, M. 2013. Allometric growth patterns of body and carcass components in Ardhi Goat. International Journal of Animal and Veterinary Advances 5:183-189.

Álvarez, J. M.; Rodríguez Iglesias, R. M.; García Vinent, G.; Giorgetti, H.; Rodriguez, G. and Baselga, M. 2013. Introduction of sheep meat breeds in extensive systems: Lamb carcass characteristics. Small Ruminant Research 109:9-14.

AOAC - Association of Official Analytical Chemistry. 1990. Official methods of analysis. 15th ed. AOAC International, Arlington, VA.

Araújo Filho, J. A. 2006. O bioma Caatinga. p.49-70. In: Semi-árido: diversidade, fragilidade e potencialidades. Sobrinho, J. F. and Falcão, C. L. C., eds. Sobral Gráfica, Sobral.

Attah, S.; Okubanjo, A. O.; Omojola, A. B. and Adesehinwa, A. O. K. 2004. Body and carcass linear measurements of goats slaughtered at different weights. Livestock Research for Rural Development 16(8). Available at: <http://www.lrrd.org/lrrd16/8/atta16062.htm> Accessed on: Mar. 5, 2012

Bezerra, S. B. L.; Veras, A. S. C.; Silva, D. K. A.; Ferreira, M. A.; Pereira, K. P.; Almeida, J. S. and Santos, J. C. A. 2010. Componentes não integrantes da carcaça de cabritos alimentados em pastejo na Caatinga. Pesquisa Agropecuária Brasileira 45:751-757.

Boggs, D. L.; Merkel, R. A. and Doumit, M. E. 1998. Livestock and carcasses. An integrated approach to evaluation, grading and selection. 5th ed. Kendall. Hunt Publishing Co. Dubuque, IA.

Carvalho Júnior, A. M.; Pereira Filho, J. M.; Silva, R. M.; Azevêdo, A. M. and Cezar, M. F. 2011. Effect of supplementation on the performance of $\mathrm{F} 1$ crossbred goats finished in native pasture. Revista Brasileira de Zootecnia 40:2510-2517.

Colomer-Rocher, F.; Delfa, R. and Sierra, I. 1988. Método normalizado para el estúdio de los caracteres cuantitativos y cualitativos de las canales, según los sistemas de produccíon. p.19-41. In: Método normalizado para el estudio de los caracteres cuantitativos y cualitativos de las canales caprinas y ovinas. INIA, Madrid.

Daskiran, I.; Bingöl, M.; Kor, A.; Demir, A. O.; Yilmaz, A. and Karaca, S. 2006a. Feedlot performance and carcass characteristics of Norduz male kids. Journal of Animal and Veterinary Advances 5:430-433.

Daskiran, I.; Kor, A. and Bingöl, M. 2006b. Slaughter and carcass characteristics of Norduz male kids raised in either intensive or pasture conditions. Pakistan Journal of Nutrition 3:274-277.

Daskiran, I.; Bingöl, M. and Karaca, S. 2010. The effect of feeding system on fattening performance, slaughter, and carcass characteristics of Norduz male kids. Tropical Animal Health and Production 42:1459-1463.

El Khidir, I. A.; Babiker, S. A. and Shafie, S. A. 1998. Comparative feedlot performance and carcass characteristics of Sudanese desert sheep and goats. Small Ruminant Research 30:147-151. 
Gökdal, Ö. 2013. Growth, slaughter and carcass characteristics of Alpine $\times$ Hair goat, Saanen $\times$ Hair goat and Hair goat male kids fed with concentrate in addition to grazing on rangeland. Small Ruminant Research 109:69-75.

Gonzaga, A. R. 2007. Estimativa de consumo e degradabilidade da extrusa em caprinos suplementados na caatinga. Dissertação (M.Sc.). Universidade Federal da Paraíba, Areia.

Grande, P. A.; Alcalde, C. R. and Lima, L.S. 2011. Carcass evaluation of Saanen kids fed oilseeds diets. Brazilian Journal of Veterinary Research and Animal Science 63:721-728.

Kadim, I. T.; Mahgoub, O.; Al-Ajmi, D. S.; Al-Maqbaly, R. S.; Al-Saqri, N. M. and Ritchie, A. 2003. An evaluation of the growth, carcass and meat quality characteristics of Omani goat breeds. Meat Science 66:203-210.

Kanani, J.; Lukefahr, S. D. and Stanko, R. L. 2006. Evaluation of tropical forage (Medicago sativa, Dolichos lablab, Leucaena leucocephala and Desmanthus bicornutus) for growing goats. Small Ruminant Research 65:1-7.

Kozloski, G. V.; Rocha, J. B. T. and Ciocca, M. L. S. 2001. Visceral metabolism and efficiency of energy use by ruminants. Ciência Rural 31:903-908.

Mattos, C. W.; Carvalho, F. F. R.; Dutra Júnior, W. M.; Véras, A. S. C.; Batista, A. M. V.; Alves, K. S.; Ribeiro, V. L.; Silva, M. J. M. S.; Medeiros, G. R.; Vasconcelos, R. M. J.; Araújo, A. O. and Miranda, S. B. 2006. Características de carcaça e dos componentes nãocarcaça de cabritos Moxotó e Canindé submetidos a dois níveis de alimentação. Revista Brasileira de Zootecnia 35:2125-2134.

Mendizabal, J. A.; Delfa, R.; Arana, A.; Eguinoa, P. and Purrov, A. 2007. Lipogenic activity in goats (Blanca celtibérica) with different body condition scores. Small Ruminant Research 67:285-290.

Monte, A. L. S.; Selaive-Villarroel, A. B.; Pérez, J. R. O.; Zapata, J. F. F.; Beserra, F. J. and Oliveira, A. N. 2007. Rendimento de cortes comerciais e composição tecidual da carcaça de cabritos mestiços. Revista Brasileira de Zootecnia 36:2127-2133.

Mourad, M.; Gbanamou, G. and Blade, I. B. 2001. Carcass characteristics of West African dwarf goats under extensive system. Small Ruminant Research 42:83-86.

NRC - National Research Council. 1981. Nutrient requirements of goats: Angora, dairy, and meat goats in temperate and tropical countries. National Academy of Science, Washington, DC.

NRC - National Research Council. 1989. Nutrient requirements of dairy cattle. 6th ed. National Academy of Science, Washington, DC.

Pereira Filho, J. M.; Resende, K. T.; Teixeira, I. A. M. A.; Silva Sobrinho, A. G.; Yánez, E. A. and Ferreira, A. C. D. 2008. Características da carcaça e alometria dos tecidos de cabritos F1 Boer $\times$ Saanen. Revista Brasileira de Zootecnia 37:905-912.

Potchoiba, M. J.; Lu, C. D.; Pinkerton, F. and Sahlu, T. 1990. Effects of all-milk diet on weight gain, organ development, carcass characteristics and tissue composition, including fatty acids and cholesterol contents, of growing male goats. Small Ruminant Research 3:583-592.

Rodrigues, L.; Gonçalves, H. C.; Medeiros, B. B. L.; Menezes, J. J. and Maestá, S. A. 2013. Evaluation of recombinant bovine somatotropin (rbst) on non-carcass components of goat kids of three genotypes. Ciência Animal Brasileira 14:143-150.

Sebsibe, A.; Casey, N. H.; Van Niekerk, W. A.; Tegegne, A. and Coertze, R. J. 2007. Growth performance and carcass characteristics of three Ethiopian goat breeds fed grainless diets varying in concentrate to roughage ratios. South African Journal of Animal Science 37:221-232.

Sheridan, R.; Ferreira, A. V.; Hoffman, L. C. and Schoeman, S. J. 2000. Effect of dietary energy level on efficiency of SA Mutton Merino lambs and Boer goat kids under feedlot conditions. South African Journal of Animal Science 30:122-123.

Silva, R. M.; Pereira Filho, J. M.; Silva, A. L. N.; Cezar, M. F.; Silva, A. M. A. and Oliveira, N. S. 2010. The effect of supplementation on the tissue composition of the commercial cuts of cross-bred F1 $($ Boer $\times$ SPRD) finished in native pasture. Revista Brasileira de Zootecnia 39:1353-1358.

Silva Sobrinho, A. G. 2001. Criação de ovinos. 2.ed. Funep, Jaboticabal.

Siqueira, E. R.; Simões, C. D. and Fernandes, S. 2001. Efeito do sexo e do peso ao abate sobre a produção de carne de cordeiro. Morfometria da carcaça, pesos dos cortes, composição tecidual e componentes não constituintes da carcaça. Revista Brasileira de Zootecnia 30:1299-1307.

Solaiman, S.; Min, B. R.; Gurung, N.; Behrends, J. and Taha, E. 2011. Assessing feed intake, growth performance, organ growth, and carcass characteristics of purebred Boer and Kiko male kids fed high concentrate diet. Small Ruminant Research 98:98-101.

Tilley, J. M. A. and Terry, R. A. 1963. A two stage technique for the in vitro digestion of forage crops. Journal of British Grassland Society 18:104-111.

Van Soest, P. J.; Robertson, J. B. and Lewis, B. A. 1991. Methods for dietary fiber, neutral detergent fiber, and non-starch polysaccharides in relation to animal nutrition. Journal Dairy Science 74:473-481.

Voet, D. and Voet, J. G. 2006. Bioquímica. 3.ed. Artmed, Porto Alegre.

Yáñez, E. A.; Resende, K. T. and Ferreira, A. C. D. 2006. Restrição alimentar em caprinos: rendimento, cortes comerciais e composição da carcaça. Revista Brasileira de Zootecnia 35:2093-2100.

Yilmaz, A.; Ekiz, B.; Özcan, M.; Kaptan, C.; Hanoglu, H. and Y1ldirır, M. 2009. Effect of crossbreeding indigenous Hair goat with Saanen on carcass measurements and meat quality of kids under an intensive production system. Animal Science Journal 80:460-467.

Yilmaz, A.; Ekiz, B.; Özcan, M.; Kaptan, C.; Hanoglu, H.; Yıldırır, M. and Kocak, 2010. Carcass quality characteristics of Hair goat and Saanen $\times$ Hair goat crossbred kids from intensive production system. Animal Feed Science and Technology 19:368-378.

Yue-Ming, W.; Wei-Lian, H. and Jian-Xin, L. 2005. Effects of supplementary urea-minerals lick block on the kinetics of fiber digestion, nutrient digestibility and nitrogen utilization of low quality roughages. Journal of Zhejiang University Science 6:793-797. 